\title{
Review
}

\section{COX-mediated endothelium-dependent contractions: from the past to recent discoveries}

\author{
Michael Sze-Ka WONG, Paul Michel VANHOUTTE* \\ Department of Pharmacology and Pharmacy, Li Ka Shing Faculty of Medicine, University of Hong Kong, Hong Kong, China
}

Endothelial cells release various substances to control the tone of the underlying vascular smooth muscle. Nitric oxide (NO) is the best defined endothelium-derived relaxing factor (EDRF). Endothelial cells can also increase vascular tone by releasing endothelium-derived contracting factors (EDCF). The over-production of EDCF contributes to the endothelial dysfunctions which accompanies various vascular diseases. The present review summarizes and discusses the mechanisms leading to the release of EDCFs derived from the metabolism of arachidonic acid. This release can be triggered by agonists such as acetylcholine, adenosine nucleotides or by stretch. All these stimuli are able to induce calcium influx into the endothelial cells, an effect which can be mimicked by calcium ionophores. The augmentation in intracellular calcium ion concentration initiates the release of EDCF. Downstream processes include activation of phospholipase $\mathrm{A}_{2}\left(\mathrm{PLA}_{2}\right)$, cyclooxygenases (COX) and the production of reactive oxygen species (ROS) and vasoconstrictor prostanoids (endoperoxides, prostacyclin, thromboxane $\mathrm{A}_{2}$ and other prostaglandins) which subsequently diffuse to, and activate thromboxaneprostanoid (TP) receptors on the vascular smooth muscle cells leading to contraction.

Keywords: cyclooxygenase; EDCF; endothelium; gap junctions; phospholipase $\mathrm{A}_{2}$; prostanoids; reactive oxygen species; TP-receptors

Acta Pharmacologica Sinica (2010) 31: 1095-1102; doi: 10.1038/aps.2010.127; published online 16 Aug 2010

\section{Introduction}

Following the first report by Furchgott and Zawadzki (1980) ${ }^{[1]}$ that in response to acetylcholine, endothelial cells release a vasodilator substance [endothelium-derived relaxing factor (EDRF)] later identified as nitric oxide (NO), a number of other inhibitory endothelial signals [endothelium-derived hyperpolarizing factors (EDHF)] have been shown to contribute to relaxations of the underlying vascular smooth muscle cells ${ }^{[2-9]}$. In addition, it soon became apparent that under certain circumstances the endothelium can also produce diffusible substances [endothelium-derived contracting factors (EDCF)] which activate the contractile process in the underlying vascular smooth muscle cells ${ }^{[10]}$. Besides receptors-mediated agonists such as thrombin, acetylcholine and adenosine nucleotides (ADP and ATP ${ }^{[11-13]}$, stretch can also elicit endotheliumdependent contractions, at least in canine cerebral arteries ${ }^{[14]}$. The early observation that such endothelium-dependent contractions could be prevented by inhibitors of cyclooxygenase suggested that down-stream products of this enzyme, ie prostanoids, were likely candidates as $\operatorname{EDCF}^{[12,15-18]}$. Although endothelial cells can produce vasoconstrictors including

\footnotetext{
* To whom correspondence should be addressed.

E-mail vanhoutt@hkucc.hku.hk

Received 2010-05-17 Accepted 2010-07-12
}

endothelin-1 and angiotensin II, there is lack of convincing evidence showing a direct link between these substances and instantaneous changes in tension that can be attributed to the release of EDCF. Thus, the present article focuses on the mechanisms leading to the production of endothelial and cyclooxygenase-derived vasoconstrictors, and updates earlier reviews on this topic ${ }^{[19-21]}$.

\section{Endothelial calcium concentration}

An increase in intracellular calcium concentration in the endothelial cells is the triggering event leading to the release of EDCF. This conclusion is based on the following observations: (a) Activation of cell membrane receptors by agonists such as acetylcholine [activating endothelial M3-muscarinic receptors $^{[22]}$, ADP and ATP [activating purinoceptors ${ }^{[11,23]}$, which are known to induce the release of calcium from the sarcoplasmic reticulum ${ }^{[24]}$, initiate the production of EDCF; (b) Reduction in the extracellular calcium concentration decreases endothelium-dependent contractions ${ }^{[25]}$; (c) Calcium ionophores such as A23187 elicit endothelium-dependent contractions $^{[13,26-29]}$; (d) Endothelium-dependent contractions induced by acetylcholine in the rat aorta are accompanied by an increase in cytosolic endothelial calcium concentration ${ }^{[26,27]}$ and this increment is greater in preparations of spontaneously hypertensive rats (SHR) compared to those of age-matched 
normotensive Wistar-Kyoto rats (WKY), in line with the larger EDCF-mediated responses in the former ${ }^{[12,15,27]}$. On the other hand, no significant difference in the increase of calcium concentration in the two strains was observed if the aortae were exposed to $\mathrm{A} 23187^{[27]}$.

\section{Phospholipase $\mathbf{A}_{2}$}

The increase in endothelial concentration of the activator ion elicited by agonists such as acetylcholine involves two steps, release of calcium from the sarcoplasmic reticulum followed by influx of extracellular calcium. Acetylcholine binds to the $G$ proteins-coupled muscarinic receptors on the endothelial cell membrane and activates phospholipase $\mathrm{C}$. The latter produces inositol triphosphate which in turn causes the release of calcium from intracellular stores. The resulting calciumdepletion process leads to the production of a messenger termed calcium influx factor $\left[\mathrm{CIF} ;{ }^{[30]}\right]$ which displaces the inhibitory calmodulin from the calcium-independent phospholipase $\mathrm{A}_{2}\left[\mathrm{iPLA}_{2}{ }^{[31-34]}\right]$. Activation of $\mathrm{iPLA}_{2}$ is an initiating event in the generation of EDCF induced by acetylcholine in the rat aorta ${ }^{[35]}$. Activated iPLA $_{2}$ produces lysophospholipids which facilitate the opening of store-operated calcium channels (SOCs) leading to the influx of extracellular calcium into the endothelial cells ${ }^{[34,36]}$. This large influx of calcium ions then activates the calcium-dependent phospholipase $\mathrm{A}_{2}\left(\mathrm{CPLA}_{2}\right)$ which converts membrane phospholipids to arachidonic acids, the precursor of prostanoids (Figure 1). That the calciumdependent form of phospholipase $\mathrm{A}_{2}$ is crucial for the ultimate production of EDCF is demonstrated by the observation that a specific inhibitor of iPLA $_{2}$ does not affect A23187-induced endothelium-dependent contractions, while quinacrine, which inhibits both forms of the enzyme, abolishes the response to both acetylcholine and A23187 $7^{[12,35]}$.

\section{Vitamin D and EDCF}

High concentrations of vitamin D appear to have an acute protective effect on endothelial cells by reducing the production of EDCF. Indeed, the in vitro administration of 1,25-dihydroxyvitamin $\mathrm{D}_{3}$ [the most active metabolite of vitamin $\mathrm{D}^{[37]}$ ] reduces EDCF-mediated responses induced by acetylcholine but not by the calcium ionophore A23187 in aorta of both SHR and WKY, suggesting that vitamin D acutely reduces EDCF production by an action upstream of the increase in calcium concentration and thus interferes with the calcium surging process (Figure 1) ${ }^{[26]}$.

\section{Cyclooxygenase}

The two isoforms of cyclooxygenase (COX), COX-1 and COX-2, have a comparable ability to catalyze the transformation of arachidonic acid into prostaglandins (Figure 2) ${ }^{[38]}$. Both isoforms can play a key role in the generation of EDCF depending on the species, the blood vessel studied and the health conditions of the donor ${ }^{[2,3,19,28,39-42]}$. COX-1 is constitutively expressed in most tissues while COX-2 is inducible $^{[43,44]}$. Early studies demonstrated that non-selective COX inhibitors abolish endothelium-dependent contractions ${ }^{[13,17]}$,

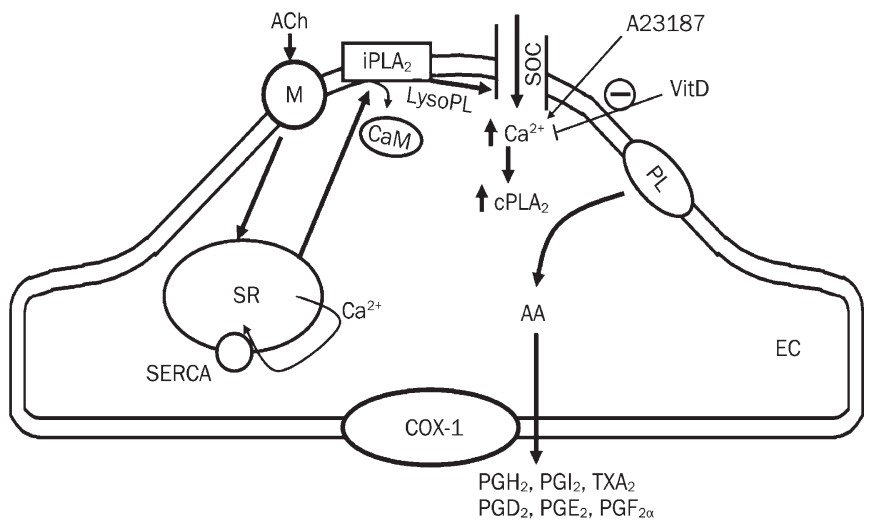

Figure 1. Acetylcholine (ACh) activates muscarinic receptors (M) on the endothelial cell membrane and triggers the release of calcium from intracellular stores. The resulting calcium-depletion process displaces the inhibitory calmodulin (CaM) from $\mathrm{PLA}_{2}$. Activated $\mathrm{PLA}_{2}$ produces lysophospholipids (LysoPL) which in turn open store-operated calcium channels (SOCs) leading to the influx of extracellular calcium into the endothelial cells. This large influx of calcium ions then activates $\mathrm{CPLA}_{2}$ which catalyze the production of arachidonic acids (AA). The later is then metabolized by cyclooxygenase-1 (COX-1) to prostanoids. 1,25-Dihydroxyvitamin $D_{3}$ (Vit $D$ ) acutely reduces endothelium-dependent contraction by inhibiting the calcium surge. $\mathrm{CPLA}_{2}=$ calcium dependent phospholipase $A_{2}$; $E C=$ endothelial cells; $i P L A_{2}=$ calcium independent phospholipase $\mathrm{A}_{2} ; \mathrm{PGD}_{2}=$ prostaglandin $\mathrm{D}_{2} ; \mathrm{PGE}_{2}=$ prostaglandin $\mathrm{E}_{2}$; $\mathrm{PGF}_{2 \alpha}=$ prostaglandin $\mathrm{F}_{2 \alpha} ; \mathrm{PGH}_{2}=$ endoperoxides; $\mathrm{PGI}_{2}=$ prostacyclin; $\mathrm{PL}=$ phospholipids; $\mathrm{SERCA}=$ sarco/endoplasmic reticulum $\mathrm{Ca}^{2+}$-ATPase; $\mathrm{SR}=$ sarcoplasmic reticulum; $\mathrm{TXA}_{2}=$ thromoboxane $\mathrm{A}_{2}$.

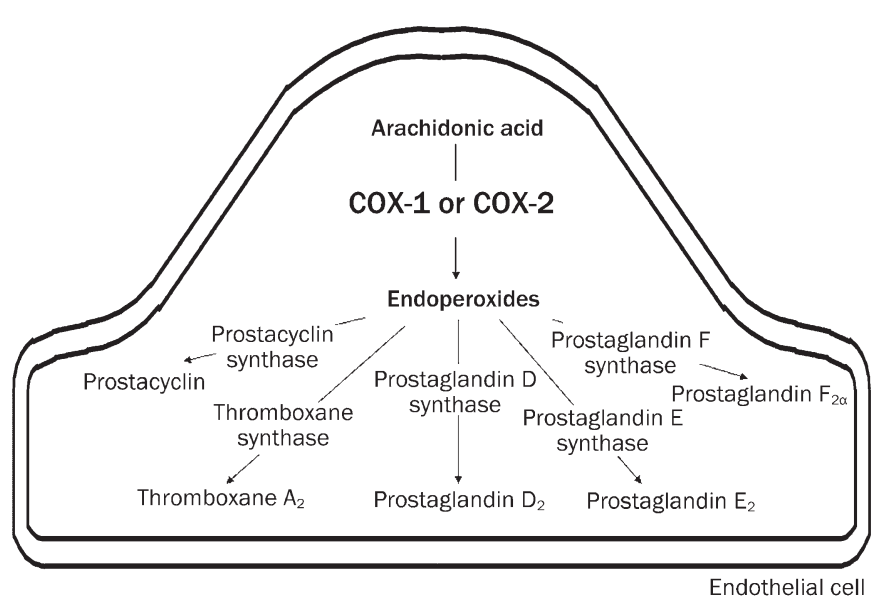

Figure 2. Metabolism of arachidonic acid into specific prostanoids. Arachidonic acid is converted to endoperoxides by the activity of cyclooxygenase (COX). Endoperoxides are then converted to various prostaglandins by their respective synthase.

an observation that has been repeated over the years. Selective inhibitors of COX-1, but not those of COX-2, abrogate endothelium-dependent contractions in the rat aorta ${ }^{[15,45-47]}$. In that preparation, COX-1 is expressed in both endothelial and vascular smooth muscle cells, but the over-expression of this 
isoform seen in the SHR aorta is confined to the endothelial cells $^{[48]}$. Likewise, bioassay studies demonstrate that only the activation of endothelial COX contributes to the generation of diffusible EDCF in the SHR aorta ${ }^{[15]}$. Endothelium-dependent contractions are present in the aorta of COX-2, but not in that of COX-1 knock-out mice ${ }^{[49]}$. Taken in conjunction, these findings demonstrated that COX-1 is the preferential constitutive isoform of cyclooxygenase which mediates endotheliumdependent contractions in large arteries of rat and mice. However, with aging or disease, COX-2 can be induced and then contributes to EDCF-mediated responses ${ }^{[50-53]}$. By contrast, constitutively expressed COX-2 plays a dominant role in the endothelium-dependent contraction of the hamster aorta irrespective of age $\mathrm{e}^{[39]}$.

\section{Prostanoids}

Cyclooxygenase converts arachidonic acid into endoperoxides $\left(\mathrm{PGH}_{2}\right)$, the intermediate of the prostanoid biosynthesis, which can either act as an EDCF per $s e^{[47,54]}$ or be further transformed into prostacyclin $\left(\mathrm{PGI}_{2}\right)$, thromboxane $\mathrm{A}_{2}$ and various other prostaglandins including prostaglandin $\mathrm{D}_{2}\left(\mathrm{PGD}_{2}\right)$, prostaglandin $\mathrm{E}_{2}\left(\mathrm{PGE}_{2}\right)$ and prostaglandin $\mathrm{F}_{2 \alpha}\left(\mathrm{PGF}_{2 \alpha}\right)$ by their respective synthases (Figure 2) ${ }^{[29,48,55,56]}$.

Although $\mathrm{PGH}_{2}$ has a relatively short half-life and is unstable ${ }^{[57]}$, it can be a vasoconstrictor $\operatorname{EDCF}^{[29,47,48,55]}$ by activating TP receptors of vascular smooth muscle $e^{[47,57,58]}$. This conclusion is supported by two observations: (a) The aorta of SHR releases more $\mathrm{PGH}_{2}$ than that of WKY when exposed to acetylcholine ${ }^{[47]}$. (b) Similarly to the acetylcholine-induced EDCF-mediated responses, $\mathrm{PGH}_{2}$-induced contractions in aortae without endothelium are transient and are larger in SHR compared to $W K Y^{[47,56]}$. In addition, when tyrosine nitration caused by the local production of peroxynitrite inhibits the activity of prostacyclin synthase ${ }^{[59]}, \mathrm{PGH}_{2}$ may become even more important in the process.

Prostacyclin is the major cyclooxygenase-derived metabolite of arachidonic acid in endothelial cells ${ }^{[60]}$. During endothelium-dependent contractions of rodent aortae in response to acetylcholine, its production is markedly larger than that of other prostaglandins and, together with $\mathrm{PGH}_{2}$, prostacyclin becomes a major $\operatorname{EDCF}^{[19,21,47,53,56]}$. This conclusion is in line with the findings that the gene expression of PGI synthase in the rat aortic endothelial cells is greatly augmented by aging and spontaneous hypertension ${ }^{[48]}$.

During ADP- and A23187-induced endothelium-dependent contractions, the release of thromboxane $\mathrm{A}_{2}$ is augmented and an inhibitor of thromboxane $\mathrm{A}_{2}$ can reduce these contractions, unlike those to acetylcholine ${ }^{[29,55,57]}$. Therefore, thromboxane $\mathrm{A}_{2}$ can be regarded as a key EDCF during the EDCF-mediated responses elicited by these agents. Likewise, in certain blood vessels (hamster aorta) or with aging and disease (such as diabetes), an augmented contribution of $\mathrm{PGE}_{2}$ and $\mathrm{PGF}_{2 \alpha}$ to EDCF-mediated contractions may become obvious ${ }^{[39,61]}$. This can be explained best by the increased generation of these prostaglandins under conditions of enhanced oxidative stress ${ }^{[62]}$, in particular as a consequence of the augmented for- mation of peroxynitrite which inhibits PGI synthase ${ }^{[59,63]}$ and diverts arachidonic acid towards $\mathrm{PGE}_{2}$ and $\mathrm{PGF}_{2 \alpha}$ synthases ${ }^{[56]}$. Obviously, the involvement of individual prostanoids in EDCF-mediated responses varies depending on the species, the blood vessels studied, the endothelium-dependent agonist used, and the age and disease state of the donor.

\section{Reactive oxygen species}

Reactive oxygen species (ROS) are generated during a number of normal metabolic activities, but their overproduction leads to oxidative stress which is commonly observed in hypertension, diabetes and atherosclerosis ${ }^{[20,64,65]}$. During the generation of prostanoids by COX, ROS are formed as by-products. ROS of relevance for endothelium-dependent responses include superoxide anions $\left(\mathrm{O}_{2}^{-}\right)$, hydroxyl radicals $(\cdot \mathrm{OH})$ and hydrogen peroxide $\left(\mathrm{H}_{2} \mathrm{O}_{2}\right)$ (Figure 3$)$. ROS either directly act as $\mathrm{EDCF}^{[66,67]}$ or indirectly potentiate EDCFmediated responses by reducing the bioavailability of $\mathrm{NO}^{[68-70]}$ and activating COX in the vascular smooth muscle cells ${ }^{[16,18,71]}$. This conclusion is based on the following observations: (a) An increased ROS production accompanies acetylcholine- or A23187-induced endothelium-dependent contractions ${ }^{[27]}$; (b) Tiron (which scavenges superoxide anions intracellularly) or catalase (which converts hydrogen peroxide to water and oxygen) plus deferoxamine (which prevents the formation of

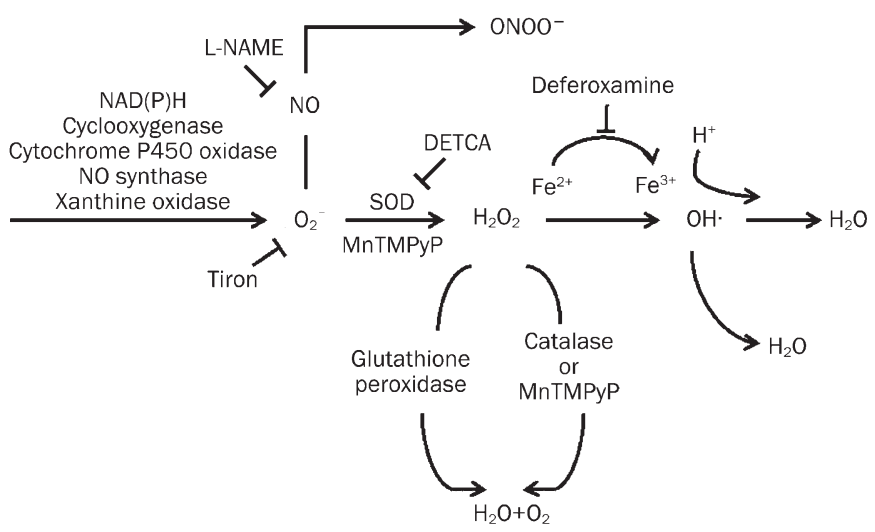

Figure 3. Formation of oxygen-derived free radicals of relevance for endothelium-dependent responses, and pharmacological agents commonly used to determine their importance. Superoxide anions $\left(\mathrm{O}_{2}{ }^{-}\right)$can be generated from molecular oxygen by the actions of various enzymes. $\mathrm{O}_{2}^{-}$can react with $\mathrm{NO}$ to form peroxynitrite $\left(\mathrm{ONOO}^{-}\right)$. It can also be converted to hydrogen peroxide $\left(\mathrm{H}_{2} \mathrm{O}_{2}\right)$ by superoxide dismutase (SOD). $\mathrm{H}_{2} \mathrm{O}_{2}$ can be transformed to hydroxyl radicals by ferrous ions or converted to $\mathrm{H}_{2} \mathrm{O}$ by catalase and glutathione. Tiron scavenges $\mathrm{O}_{2}^{-}$inside cells. DETCA inhibits SOD. Deferoxamine is an iron chelator that scavenges hydroxyl radicals. L-NAME inhibits NO synthase. MnTMPyP mimics the combined effect of SOD and catalase. DETCA=diethyldithiocarbamic acid; GSH=glutathione; GSSG=glutathione disulphide; L-NAME $=N^{\omega}$ nitro-L-arginine methyl ester hydrochloride; MnTMPyP=Mn(III)tetrakis(1methyl-4-pyridyl)porphyrin pentachloride; $N O=$ nitric oxide; tiron=4,5dihydroxy-1,3-benzenedisulphonic acid. (Adapted from Shi et al 2007, by permission)Arachidonic acid is converted to endoperoxides by the activity of cyclooxygenase (COX). Endoperoxides are then converted to various prostaglandins by their respective synthase. 
hydroxyl radicals) reduce endothelium-dependent contractions in the SHR aorta ${ }^{[72]}$ and the femoral artery of diabetic rats $^{[64]}$, suggesting that superoxide anions and hydrogen peroxide augment or even mediate part of the response; (c) ROS formed by the xanthine plus xanthine oxidase reaction elicit contractions of SHR aortae without endothelium which are prevented by both COX inhibitors and TP receptor antagonists, suggesting that the oxygen-derived free radicals stimulate COX in the vascular smooth muscle to produce prostanoids which in turn activate their TP receptors ${ }^{[18,72]}$. (d) ROS increase the degradation of nitric oxide ${ }^{[68,69]}$; (d) Peroxynitrite, a strong cytosolic oxidant generated by the reaction of the superoxide anions and nitric oxide, inactivate PGI synthase ${ }^{[59,63]}$ and shifts the production of prostacyclin to that of other vasoconstrictor prostanoids $s^{[5,73]}$. (e) In canine basilar arteries, superoxide dismutase (SOD) plus catalase abolish the A23187 induced endothelium-dependent contractions but not the production of prostaglandins and thromboxane $\mathrm{A}_{2}$ indicating that ROS rather than COX-derived prostanoids are the EDCF in this particular artery ${ }^{[66]}$; (f) In the rat pulmonary artery, ROS induce contraction involving the activity of protein kinase $\mathrm{C}$ in the vascular smooth muscle ${ }^{[74]}$; (g) In vascular smooth muscle of the rat aorta, the ROS-induced calcium sensitization is mediated through the activation of Rho and a subsequent increase in Rho kinase activity ${ }^{[75]}$, and the latter is crucial in the response to EDCF ${ }^{[76]}$; and (h) ROS directly depolarize vascular smooth muscle by inhibiting ATP-sensitive potassium channel $\left(\mathrm{K}_{\mathrm{ATP}}\right)$, voltage-activated potassium channel $\left(\mathrm{K}_{\mathrm{v}}\right)$ and large conductance calcium-activated potassium channel $\left(\mathrm{BK}_{\mathrm{Ca}}\right)^{[77-79]}$.

\section{Gap junctions}

The contact between endothelial and vascular smooth muscle cells is important in the genesis of endothelium-dependent contractions. This conclusion is supported by the observation that the endothelium-dependent contractile response to acetylcholine of layered bioassay ("sandwich") preparations of SHR aortae is much smaller than that of intact aortic ring ${ }^{[72]}$. The contraction in the "sandwich preparation" is caused by prostanoids which diffuse across the intracellular gap between the donor (containing endothelial cells) and the recipient strip (without endothelium, responsible for the contraction). Under bioassay conditions, superoxide dismutase plus catalase (both compounds with poor cell permeability) can reduce the acetylcholine-induced endothelium-dependent contractions while they have no effect in intact rings in which tiron inhibits EDCF-mediated responses ${ }^{[15,18]}$. These observations imply that in intact rings, ROS exert their facilitatory effect by either acting in the endothelial cells or being transported from the latter to the vascular smooth muscle cells via preferential channels not accessible to superoxide dismutase. One possible route would be the myoendothelial gap junctions (Figure 4), since the gap junction inhibitor carbenoxolone reduces endothelium-dependent contractions to acetylcholine and the calcium ionophore $\mathrm{A} 23187^{[80]}$.

\section{Prostanoid receptors and Rho kinase}

Thromboxane-prostanoid receptors (TP-receptors) are the most important prostanoid receptor subtype involved in endothelium-dependent contractions since TP receptor antagonists abolish these responses ${ }^{[15,57,81]}$. All prostanoids are able to bind with TP receptors, albeit with different affinities ${ }^{[82]}$. Thromboxane $\mathrm{A}_{2}$ is the most potent agonist at TP receptors. Endoperoxides and prostacyclin also activate TP receptors and both of them evoke transient contractions (probably due to their short half-life) which mimic acetylcholine-induced endothelium-dependent contractions ${ }^{[56]}$. Binding of EDCF to the TP receptors in turn activates the downstream Rho kinase pathway leading to the increased contractile activity of the vascular smooth muscle ${ }^{[76]}$.

In the SHR aorta, the gene expression levels and protein presence of TP receptors are not altered, but the responsiveness to endoperoxides is augmented compared to WKY preparations ${ }^{[47,48]}$. This hyperresponsiveness contributes to the prominence of EDCF-mediated responses in the aorta of the SHR. Another crucial aspect in this prominence is that the vascular smooth muscle of aging WKY and of the SHR have lost the ability to respond with relaxation to prostacyclin, despite an unchanged expression of IP receptors and the large production of prostacyclin by endothelial cells exposed to acetycholine or A23187 $7^{[48,56,83,84]}$.

\section{Interactions between NO, EDHF, and EDCF}

In the SHR aorta, the concomitant release of NO inhibits endothelium-dependent contractions to acetylcholine ${ }^{[85,86]}$, an observation that has lead to the systematic use of inhibitors of NO synthases when studying EDCF-mediated responses. In addition, previous exposure to endothelium-derived $\mathrm{NO}$ or exogenous NO-donors causes a long-term inhibition of EDCFmediated responses ${ }^{[87,88]}$. Likewise, in the renal artery of the rat, the absence of EDHF favours the occurrence of endothelium-dependent contractions ${ }^{[9]}$.

Alternatively, EDCF may also counteract the action of endothelium-derived relaxing factors. Thus, in WKY mesenteric artery, EDHF-mediated relaxations are attenuated by the release of $\mathrm{EDCF}^{[89]}$. This attenuation is explained best by the EDCF-induced activation of TP-receptors which depolarizes the vascular smooth muscle cells by inhibiting $\mathrm{K}_{\mathrm{v}}$ and $\mathrm{BK}_{\mathrm{Ca}}{ }^{[90,91]}$.

\section{Physiological importance}

In the early nineteenth century, Bayliss showed that an increase in the internal pressure in the carotid artery of the dog caused its constriction, a seminal observation leading to the concept of autoregulation ${ }^{[92]}$. In isolated basilar arteries of the same species, stretch induces a contraction which disappears after the removal of the endothelium, demonstrating an endothelium-dependent process ${ }^{[14]}$. This contraction is sensitive to both the COX inhibitor indomethacin and the calciuminflux blocker diltiazem, suggesting that the activity of COX (presumably in the endothelial cells) and the influx of extracel- 


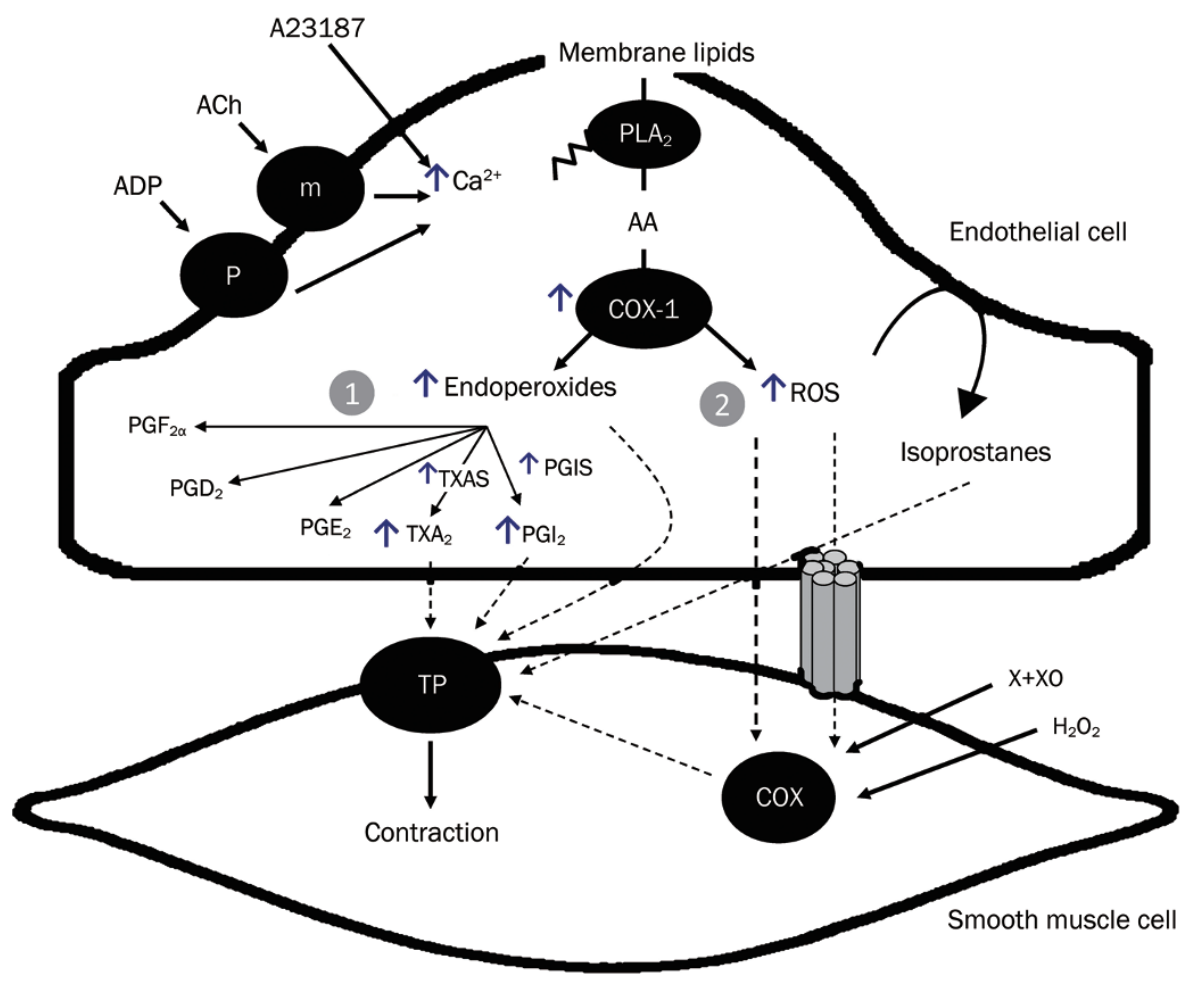

Figure 4. Endothelium-dependent contraction is likely to be comprised of two components: generation of prostanoids and ROS. Each component depends on the activity of endothelial COX-1 and the stimulation of the TP receptors located on the smooth muscle to evoke contraction. In the SHR aorta, there is an increased expression of COX-1 and EP3 receptors, increased release of calcium, ROS, endoperoxides and other prostanoids, which facilitates the greater occurrence of endothelium-dependent contraction in the hypertensive rat. The necessary increase in intracellular calcium can be triggered by receptor-dependent agonists, such as acetylcholine or ADP, or mimicked with calcium increasing agents, such as the calcium ionophore A23187. The abnormal increase in intracellular ROS can be mimicked by the exogenous addition of $\mathrm{H}_{2} \mathrm{O}_{2}$ or the generation of extracellular ROS by incubation of xanthine with xanthine oxidase. $A A=$ arachidonic acid; $A C h=$ acetycholine; $A D P=$ adenosine diphosphate; $\mathrm{H}_{2} \mathrm{O}_{2}=$ hydrogen peroxide; $m=$ muscarinic receptors; $P=$ purinergic receptors; $P \mathrm{PD}_{2}=$ prostaglandin $\mathrm{D} 2 ; \mathrm{PGE}_{2}=$ prostaglandin $\mathrm{E}_{2} ; \mathrm{PGF}_{2 \alpha}=$ prostaglandin $\mathrm{F}_{2 \alpha} ; \mathrm{PGI} \mathrm{I}_{2}=$ prostacyclin; $\mathrm{PLA}_{2}=$ phospholipase $\mathrm{A}_{2} ; \mathrm{ROS}=$ reactive oxygen species; $\mathrm{TXA}_{2}=$ thromboxane $\mathrm{A}_{2} ; \mathrm{X}+\mathrm{XO}=x$ anthine plus xanthine oxidase. (Adapted from Tang and Vanhoutte, 2009, by permission).

lular calcium (presumably in the vascular smooth muscle cells) are required for the active response to stretch ${ }^{[14]}$. Likewise, in bovine coronary arteries, stretch elicits an endothelium-independent contraction which requires the activation of $\mathrm{NAD}(\mathrm{P})$ $\mathrm{H}$ oxidase ${ }^{[93]}$. Stretch also directly activates various cation channels on the smooth muscle cells of small arteries facilitating their contraction ${ }^{[94-96]}$. Oxygen-derived free radicals play a key role in endothelium-dependent contractions of the canine basilar artery ${ }^{[66]}$. Thus, it is tempting to speculate that the endothelium-dependent contraction evoked by stretch (resulting from activation of endothelial COX, the production of ROS and the hypersensitivity of the vascular smooth muscle) may initiate the autoregulatory response, at least in cerebral arteries.

\section{Pathophysiological relevance}

As mentioned already, endothelium-dependent contractions are exacerbated by aging, diabetes, hypertension and atherosclerosis $^{[41,97,98]}$. Foe example, the blunted endotheliumdependent relaxations in response to acetylcholine in diabetic animals is partly due to the augmented production of EDCF, resulting from the over-expression and activation of COX and increased ROS production after the chronic exposure of the endothelial cells to high glucose levels ${ }^{[99]}$. In essential hypertensive patients, the blunted vasodilatation induced by acetylcholine can almost be normalized by the COX inhibitor indomethacin indicating that COX-derived vasoconstrictors are key players responsible for the abnormal endothelial response ${ }^{[100]}$. This indomethacin-sensitive impairment of the response to acetylcholine is accentuated by aging ${ }^{[98]}$. However, in secondary hypertension, inhibition of COX does not restore the acetylcholine-induced vasodilatation suggesting that EDCFs are not equally important in all cases of hypertension. It is likely that the prominence of endothelium-dependent contractions observed in arteries of aging and diseased (essential hypertension, diabetes) animals and human reflects the progressive inability of the endothelial cells to generate enough NO to curtail the production of $\operatorname{EDCF}^{[40,87,88]}$. Shifting from the normal release of NO (and EDHF) to that of EDCF likely plays an important role in the development of vascular disease ${ }^{[40,101]}$. 


\section{Conclusion}

Endothelial cells release COX-derived vasoconstrictor prostanoids and reactive oxygen species, which have been termed EDCF. In the SHR, prostacyclin becomes a prominent EDCF acting on TP-receptors, even more so that IP receptor signaling is impaired ${ }^{[21,56,83]}$. EDCF-mediated responses are amplified in aging normotensive animals (Koga et al, 1989; Wong et al, 2009), hypertensive $\mathrm{e}^{[12]}$ and diabetic ${ }^{[20,50,64,102]}$ animals. In humans, EDCF plays a role in the endothelial dysfunction that accompanies aging, atherosclerosis, myocardial infarction and essential hypertension ${ }^{[98,103,104]}$.

\section{References}

1 Furchgott RF, Zawadzki JV. The obligatory role of endothelial-cells in the relaxation of arterial smooth-muscle by acetylcholine. Nature 1980; 288: 373-76.

2 Furchgott RF, Vanhoutte PM. Endothelium-derived relaxing and contracting factors. FASEB J 1989; 3: 2007-18.

3 Luescher TF, Vanhoutte PM. The Endothelium: Modulator of Cardiovascular Function Boca Raton, FL CRC Press; 1990.

4 Vanhoutte PM. The other endothelium-derived vasoactive factors. Circulation 1993; 87: V9-17.

5 Gluais P, Edwards G, Weston AH, Vanhoutte PM, Feletou M. Hydrogen peroxide and endothelium-dependent hyperpolarization in the guinea-pig carotid artery. Eur J Pharmacol 2005; 513: 219-24.

6 Gluais P, Edwards G, Weston AH, Falck JR, Vanhoutte PM, Feletou M. Role of $\mathrm{SK}_{\mathrm{Ca}}$ and $\mathrm{IK}_{\mathrm{Ca}}$ in endothelium-dependent hyperpolarizations of the guinea-pig isolated carotid artery. Br J Pharmacol 2005; 144: 477-85.

7 Feletou M, Vanhoutte PM. EDHF: the complete story CRC Press; 2006.

8 Shi Y, Ku DD, Man RY, Vanhoutte PM. Augmented endotheliumderived hyperpolarizing factor-mediated relaxations attenuate endothelial dysfunction in femoral and mesenteric, but not in carotid arteries from type I diabetic rats. J Pharmacol Exp Ther 2006; 318: 276-81.

9 Michel FS, Man GS, Man RY, Vanhoutte PM. Hypertension and the absence of EDHF-mediated responses favour endothelium-dependent contractions in renal arteries of the rat. $\mathrm{Br} J$ Pharmacol 2008; 155: $217-26$.

10 De Mey JG, Vanhoutte PM. Heterogeneous behavior of the canine arterial and venous wall. Importance of the endothelium. Circ Res 1982; 51: 439-47.

11 Mombouli JV, Vanhoutte PM. Purinergic endothelium-dependent and -independent contractions in rat aorta. Hypertension 1993; 22: 577-83.

12 Luescher TF, Vanhoutte PM. Endothelium-dependent contractions to acetylcholine in the aorta of the spontaneously hypertensive rat. Hypertension 1986; 8: 344-8.

13 Katusic ZS, Shepherd JT, Vanhoutte PM. Endothelium-dependent contractions to calcium ionophore A23187, arachidonic acid, and acetylcholine in canine basilar arteries. Stroke 1988; 19: 476-9.

14 Katusic ZS, Shepherd JT, Vanhoutte PM. Endothelium-dependent contraction to stretch in canine basilar arteries. Am J Physiol 1987; 252: H671-3.

15 Yang D, Feletou M, Levens N, Zhang JN, Vanhoutte PM. A diffusible substance(s) mediates endothelium-dependent contractions in the aorta of SHR. Hypertension 2003; 41: 143-8.

16 Yang D, Feletou M, Boulanger CM, Wu HF, Levens N, Zhang JN, et al. Oxygen-derived free radicals mediate endothelium-dependent contractions to acetylcholine in aortas from spontaneously hypertensive rats. Br J Pharmacol 2002; 136: 104-10.

17 Miller VM, Vanhoutte PM. Endothelium-dependent contractions to arachidonic acid are mediated by products of cyclooxygenase. Am J Physiol 1985; 248: H432-7.

18 Auch-Schwelk W, Katusic ZS, Vanhoutte PM. Contractions to oxygenderived free radicals are augmented in aorta of the spontaneously hypertensive rat. Hypertension 1989; 13: 859-64.

19 Tang EH, Vanhoutte PM. Prostanoids and reactive oxygen species: team players in endothelium-dependent contractions. Pharmacol Ther 2009; 122: 140-9.

20 Shi Y, Vanhoutte PM. Reactive oxygen-derived free radicals are key to the endothelial dysfunction of diabetes. J Diabetes 2009; 1: 15162.

21 Feletou M, Verbeuren TJ, Vanhoutte PM. Endothelium-dependent contractions in SHR: a tale of prostanoid TP and IP receptors. $\mathrm{Br} J$ Pharmacol 2009; 156: 563-74.

22 Boulanger CM, Morrison KJ, Vanhoutte PM. Mediation by M3muscarinic receptors of both endothelium-dependent contraction and relaxation to acetylcholine in the aorta of the spontaneously hypertensive rat. Br J Pharmacol 1994; 112: 519-24.

23 Koga T, Takata Y, Kobayashi K, Takishita S, Yamashita Y, Fujishima M. Age and hypertension promote endothelium-dependent contractions to acetylcholine in the aorta of the rat. Hypertension 1989; 14: 542-8.

24 Liu QH, Zheng YM, Korde AS, Yadav VR, Rathore R, Wess J, et al. Membrane depolarization causes a direct activation of $\mathrm{G}$ proteincoupled receptors leading to local $\mathrm{Ca}^{2+}$ release in smooth muscle. Proc Natl Acad Sci USA 2009; 106: 11418-23.

25 Okon EB, Golbabaie A, van Breemen C. In the presence of L-NAME SERCA blockade induces endothelium-dependent contraction of mouse aorta through activation of smooth muscle prostaglandin $\mathrm{H} 2$ / thromboxane A2 receptors. Br J Pharmacol 2002; 137: 545-53.

26 Wong MS, Delansorne R, Man RY, Vanhoutte PM. Vitamin D derivatives acutely reduce endothelium-dependent contractions in the aorta of the spontaneously hypertensive rat. Am J Physiol Heart Circ Physiol 2008; 295: H289-96.

27 Tang EH, Leung FP, Huang Y, Feletou M, So KF, Man RY, et al. Calcium and reactive oxygen species increase in endothelial cells in response to releasers of endothelium-derived contracting factor. $\mathrm{Br} \mathrm{J}$ Pharmacol 2007; 151: 15-23.

28 Shi Y, Feletou M, Ku DD, Man RY, Vanhoutte PM. The calcium ionophore A23187 induces endothelium-dependent contractions in femoral arteries from rats with streptozotocin-induced diabetes. $\mathrm{Br} J$ Pharmacol 2007; 150: 624-32.

29 Gluais P, Paysant J, Badier-Commander C, Verbeuren T, Vanhoutte PM, Feletou M. In SHR aorta, calcium ionophore A-23187 releases prostacyclin and thromboxane A2 as endothelium-derived contracting factors. Am J Physiol Heart Circ Physiol 2006; 291: H2255-64.

30 Randriamampita C, Tsien RY. Emptying of intracellular $\mathrm{Ca}^{2+}$ stores releases a novel small messenger that stimulates $\mathrm{Ca}^{2+}$ influx. Nature 1993; 364: 809-14.

31 Wolf MJ, Wang J, Turk J, Gross RW. Depletion of intracellular calcium stores activates smooth muscle cell calcium-independent phospholipase A2. A novel mechanism underlying arachidonic acid mobilization. J Biol Chem 1997; 272: 1522-6.

32 Wolf MJ, Gross RW. The calcium-dependent association and functional coupling of calmodulin with myocardial phospholipase A2. Implications for cardiac cycle-dependent alterations in phospholipolysis. J Biol Chem 1996; 271: 20989-92.

33 Trepakova ES, Csutora P, Hunton DL, Marchase RB, Cohen RA, 
Bolotina VM. Calcium influx factor directly activates store-operated cation channels in vascular smooth muscle cells. J Biol Chem 2000; 275: 26158-63.

34 Smani T, Zakharov SI, Csutora P, Leno E, Trepakova ES, Bolotina VM. A novel mechanism for the store-operated calcium influx pathway. Nat Cell Biol 2004; 6: 113-20.

35 Wong MS, Man RY, Vanhoutte PM. Calcium-independent phospholipase A2 plays a key role in the endothelium-dependent contractions to acetylcholine in the aorta of SHR. Am J Physiol Heart Circ Physiol 2010; 298: H1260-6.

36 Trepakova ES, Gericke M, Hirakawa Y, Weisbrod RM, Cohen RA, Bolotina VM. Properties of a native cation channel activated by $\mathrm{Ca}^{2+}$ store depletion in vascular smooth muscle cells. J Biol Chem 2001; 276: 7782-90.

37 Holick MF. Vitamin D: A millenium perspective. J Cell Biochem 2003; 88: 296-307.

38 Garavito RM, DeWitt DL. The cyclooxygenase isoforms: structural insights into the conversion of arachidonic acid to prostaglandins. Biochim Biophys Acta 1999; 1441: 278-87.

39 Wong SL, Leung FP, Lau CW, Au CL, Yung LM, Yao X, et al. Cyclooxygenase-2-derived prostaglandin F2alpha mediates endotheliumdependent contractions in the aortae of hamsters with increased impact during aging. Circ Res 2009; 104: 228-35.

40 Vanhoutte PM, Shimokawa H, Tang EH, Feletou M. Endothelial dysfunction and vascular disease. Acta Physiol (Oxf) 2009; 196: 193-222.

41 Vanhoutte PM. COX-1 and vascular disease. Clin Pharmacol Ther 2009; 86: 212-5.

42 Kauser K, Rubanyi GM. Gender difference in endothelial dysfunction in the aorta of spontaneously hypertensive rats. Hypertension 1995; 25: 517-23.

43 Vane JR, Bakhle YS, Botting RM. Cyclooxygenases 1 and 2. Annu Rev Pharmacol Toxicol 1998; 38: 97-120.

44 Davidge ST. Prostaglandin $\mathrm{H}$ synthase and vascular function. Circ Res 2001; 89: 650-60.

45 Yang D, Gluais P, Zhang JN, Vanhoutte PM, Feletou M. Endotheliumdependent contractions to acetylcholine, ATP and the calcium ionophore A 23187 in aortas from spontaneously hypertensive and normotensive rats. Fundam Clin Pharmacol 2004; 18: 321-6.

46 Ospina JA, Duckles SP, Krause DN. 17 beta-estradiol decreases vascular tone in cerebral arteries by shifting COX-dependent vasoconstriction to vasodilation. Am J Physiol Heart Circ Physiol 2003; 285: H241-50.

47 Ge T, Hughes H, Junquero DC, Wu KK, Vanhoutte PM, Boulanger $\mathrm{CM}$. Endothelium-dependent contractions are associated with both augmented expression of prostaglandin $\mathrm{H}$ synthase-1 and hypersensitivity to prostaglandin H2 in the SHR aorta. Circ Res 1995; 76 : 1003-10.

48 Tang EH, Vanhoutte PM. Gene expression changes of prostanoid synthases in endothelial cells and prostanoid receptors in vascular smooth muscle cells caused by aging and hypertension. Physiol Genomics 2008; 32: 409-18.

49 Tang EH, Ku DD, Tipoe GL, Feletou M, Man RY, Vanhoutte PM. Endothelium-dependent contractions occur in the aorta of wild-type and $\mathrm{COX}^{-/-}$knockout but not $\mathrm{COX} 1^{-/-}$knockout mice. J Cardiovasc Pharmacol 2005; 46: 761-5.

50 Shi Y, Man RY, Vanhoutte PM. Two isoforms of cyclooxygenase contribute to augmented endothelium-dependent contractions in femoral arteries of 1-year-old rats. Acta Pharmacol Sin 2008; 29: 185-92.

51 Matsumoto T, Ishida K, Kobayashi T, Kamata K. Pyrrolidine dithiocarbamate reduces vascular prostanoid-induced responses in aged type 2 diabetic rat model. J Pharmacol Sci 2009; 110: 326-33.

52 Camacho M, Lopez-Belmonte J, Vila L. Rate of vasoconstrictor prostanoids released by endothelial cells depends on cyclooxygenase-2 expression and prostaglandin I synthase activity. Circ Res 1998; 83: 353-65.

53 Blanco-Rivero J, Cachofeiro V, Lahera V, Aras-Lopez R, MarquezRodas I, Salaices M, et al. Participation of prostacyclin in endothelial dysfunction induced by aldosterone in normotensive and hypertensive rats. Hypertension 2005; 46: 107-12.

54 Asano $\mathrm{H}$, Shimizu K, Muramatsu M, Iwama Y, Toki Y, Miyazaki Y, et al. Prostaglandin $\mathrm{H} 2$ as an endothelium-derived contracting factor modulates endothelin-1-induced contraction. J Hypertens 1994; 12 : 383-90.

55 Gluais P, Vanhoutte PM, Feletou M. Mechanisms underlying ATPinduced endothelium-dependent contractions in the SHR aorta. Eur J Pharmacol 2007; 556: 107-14.

56 Gluais P, Lonchampt M, Morrow JD, Vanhoutte PM, Feletou M. Acetylcholine-induced endothelium-dependent contractions in the SHR aorta: the Janus face of prostacyclin. Br J Pharmacol 2005; 146: 834-45.

57 Auch-Schwelk W, Katusic ZS, Vanhoutte PM. Thromboxane A2 receptor antagonists inhibit endothelium-dependent contractions. Hypertension 1990; 15: 699-703.

58 Ito T, Kato T, Iwama Y, Muramatsu M, Shimizu K, Asano H, et al. Prostaglandin $\mathrm{H} 2$ as an endothelium-derived contracting factor and its interaction with endothelium-derived nitric oxide. J Hypertens 1991; 9: 729-36.

59 Zou MH, Shi C, Cohen RA. High glucose via peroxynitrite causes tyrosine nitration and inactivation of prostacyclin synthase that is associated with thromboxane/prostaglandin $\mathrm{H}(2)$ receptor-mediated apoptosis and adhesion molecule expression in cultured human aortic endothelial cells. Diabetes 2002; 51: 198-203.

60 Moncada S, Gryglewski RJ, Bunting S, Vane JR. An enzyme isolated from arteries transforms prostaglandin endoperoxides to an unstable substance that inhibits platelet aggregation. Nature 1976; 263: 663-65.

61 Matsumoto T, Nakayama N, Ishida K, Kobayashi T, Kamata K. Eicosapentaenoic acid improves imbalance between vasodilator and vasoconstrictor actions of endothelium-derived factors in mesenteric arteries from rats at chronic stage of type 2 diabetes. J Pharmacol Exp Ther 2009; 329: 324-34.

62 Gryglewski RJ, Palmer RM, Moncada S. Superoxide anion is involved in the breakdown of endothelium-derived vascular relaxing factor. Nature 1986; 320: 454-6.

63 Zou MH, Leist M, Ullrich V. Selective nitration of prostacyclin synthase and defective vasorelaxation in atherosclerotic bovine coronary arteries. Am J Pathol 1999; 154: 1359-65.

64 Shi Y, So KF, Man RY, Vanhoutte PM. Oxygen-derived free radicals mediate endothelium-dependent contractions in femoral arteries of rats with streptozotocin-induced diabetes. Br J Pharmacol 2007; 152: 1033-41.

65 Liu H, Colavitti R, Rovira, II, Finkel T. Redox-dependent transcriptional regulation. Circ Res 2005; 97: 967-74.

66 Katusic ZS, Vanhoutte PM. Superoxide anion is an endotheliumderived contracting factor. Am J Physiol 1989; 257: H33-7.

67 Katusic ZS, Schugel J, Cosentino F, Vanhoutte PM. Endotheliumdependent contractions to oxygen-derived free radicals in the canine basilar artery. Am J Physiol 1993; 264: H859-64.

68 Rubanyi GM, Vanhoutte PM. Superoxide anions and hyperoxia inactivate endothelium-derived relaxing factor. Am J Physiol 1986; 250: H822-7. 
69 Paolocci N, Biondi R, Bettini M, Lee Cl, Berlowitz CO, Rossi R, et al. Oxygen radical-mediated reduction in basal and agonist-evoked NO release in isolated rat heart. J Mol Cell Cardiol 2001; 33: 671-9.

70 Huie RE, Padmaja S. The reaction of no with superoxide. Free Radic Res Commun 1993; 18: 195-9.

71 Hibino M, Okumura K, Iwama Y, Mokuno S, Osanai H, Matsui H, et al. Oxygen-derived free radical-induced vasoconstriction by thromboxane A2 in aorta of the spontaneously hypertensive rat. J Cardiovasc Pharmacol 1999; 33: 605-10.

72 Yang D, Levens N, Zhang JN, Vanhoutte PM, Feletou M. Specific potentiation of endothelium-dependent contractions in SHR by tetrahydrobiopterin. Hypertension 2003; 41: 136-42.

73 Cohen RA. Does EDCF contribute to diabetic endothelial cell dysfunction. Dialog Cardiovasc Med 2002; 7: 225-31.

74 Jin N, Packer CS, Rhoades RA. Reactive oxygen-mediated contraction in pulmonary arterial smooth muscle: cellular mechanisms. Can J Physiol Pharmacol 1991; 69: 383-8.

75 Jin L, Ying Z, Webb RC. Activation of Rho/Rho kinase signaling pathway by reactive oxygen species in rat aorta. Am J Physiol Heart Circ Physiol 2004; 287: H1495-500.

76 Chan CK, Mak JC, Man RY, Vanhoutte PM. Rho kinase inhibitors prevent endothelium-dependent contractions in the rat aorta. J Pharmacol Exp Ther 2009; 329: 820-6.

77 Tang XD, Garcia ML, Heinemann SH, Hoshi T. Reactive oxygen species impair Slo1 BK channel function by altering cysteinemediated calcium sensing. Nat Struct Mol Biol 2004; 11: 171-8.

78 Li H, Gutterman DD, Rusch NJ, Bubolz A, Liu Y. Nitration and functional loss of voltage-gated $\mathrm{K}^{+}$channels in rat coronary microvessels exposed to high glucose. Diabetes 2004; 53: 2436-42.

79 Kinoshita H, Azma T, Nakahata K, Iranami H, Kimoto Y, Dojo M, et al. Inhibitory effect of high concentration of glucose on relaxations to activation of ATP-sensitive $\mathrm{K}^{+}$channels in human omental artery. Arterioscler Thromb Vasc Biol 2004; 24: 2290-5.

80 Tang EH, Vanhoutte PM. Gap junction inhibitors reduce endotheliumdependent contractions in the aorta of spontaneously hypertensive rats. J Pharmacol Exp Ther 2008; 327: 148-53.

81 Kato T, Iwama Y, Okumura K, Hashimoto H, Ito T, Satake T. Prostaglandin $\mathrm{H} 2$ may be the endothelium-derived contracting factor released by acetylcholine in the aorta of the rat. Hypertension 1990; 15: 475-81.

82 Dickinson JS, Murphy RC. Mass spectrometric analysis of leukotriene A4 and other chemically reactive metabolites of arachidonic acid. J Am Soc Mass Spectrom 2002; 13: 1227-34.

83 Rapoport RM, Williams SP. Role of prostaglandins in acetylcholineinduced contraction of aorta from spontaneously hypertensive and Wistar-Kyoto rats. Hypertension 1996; 28: 64-75.

84 Levy JV. Prostacyclin-induced contraction of isolated aortic strips from normal and spontaneously hypertensive rats (SHR). Prostaglandins 1980; 19: 517-25.

85 Yang D, Gluais P, Zhang JN, Vanhoutte PM, Feletou M. Nitric oxide and inactivation of the endothelium-dependent contracting factor released by acetylcholine in spontaneously hypertensive rat. J Cardiovasc Pharmacol 2004; 43: 815-20.

86 Auch-Schwelk W, Katusic ZS, Vanhoutte PM. Nitric oxide inactivates endothelium-derived contracting factor in the rat aorta. Hypertension 1992; 19: 442-5.

87 Tang EH, Feletou M, Huang Y, Man RY, Vanhoutte PM. Acetylcholine and sodium nitroprusside cause long-term inhibition of EDCFmediated contractions. Am J Physiol Heart Circ Physiol 2005; 289 : H2434-40.

88 Feletou M, Tang EH, Vanhoutte PM. Nitric oxide the gatekeeper of endothelial vasomotor control. Front Biosci 2008; 13: 4198-217.

89 Sekiguchi F, Nakahira T, Kawata K, Sunano S. Responses to endothelium-derived factors and their interaction in mesenteric arteries from Wistar-Kyoto and stroke-prone spontaneously hypertensive rats. Clin Exp Pharmacol Physiol 2002; 29: 1066-74.

90 Scornik FS, Toro L. U46619, a thromboxane A2 agonist, inhibits KCa channel activity from pig coronary artery. Am J Physiol 1992; 262 : C708-13.

91 Cogolludo A, Moreno L, Bosca L, Tamargo J, Perez-Vizcaino F. Thromboxane A2-induced inhibition of voltage-gated $\mathrm{K}^{+}$channels and pulmonary vasoconstriction: role of protein kinase Czeta. Circ Res 2003; 93: 656-63.

92 Bayliss WM. On the local reactions of the arterial wall to changes of internal pressure. J Physiol 1902; 28: 220-31.

93 Oeckler RA, Kaminski PM, Wolin MS. Stretch enhances contraction of bovine coronary arteries via an $\mathrm{NAD}(\mathrm{P}) \mathrm{H}$ oxidase-mediated activation of the extracellular signal-regulated kinase mitogen-activated protein kinase cascade. Circ Res 2003; 92: 23-31.

94 Wu X, Davis MJ. Characterization of stretch-activated cation current in coronary smooth muscle cells. Am J Physiol Heart Circ Physiol 2001; 280: H1751-61.

95 Setoguchi M, Ohya Y, Abe I, Fujishima M. Stretch-activated whole-cell currents in smooth muscle cells from mesenteric resistance artery of guinea-pig. J Physiol 1997; 501: 343-53.

96 Hill MA, Zou H, Potocnik SJ, Meininger GA, Davis MJ. Invited review: arteriolar smooth muscle mechanotransduction: $\mathrm{Ca}^{2+}$ signaling pathways underlying myogenic reactivity. J Appl Physiol 2001; 91: 973-83.

97 Vanhoutte PM, Tang EH. Endothelium-dependent contractions: when a good guy turns bad! J Physiol 2008; 586: 5295-304.

98 Taddei S, Virdis A, Ghiadoni L, Versari D, Salvetti A. Endothelium, aging, and hypertension. Curr Hypertens Rep 2006; 8: 84-9.

99 De Vriese AS, Verbeuren TJ, Van de Voorde J, Lameire NH, Vanhoutte PM. Endothelial dysfunction in diabetes. Br J Pharmacol 2000; 130: 963-74.

100 Taddei S, Virdis A, Ghiadoni L, Magagna A, Salvetti A. Vitamin C improves endothelium-dependent vasodilation by restoring nitric oxide activity in essential hypertension. Circulation 1998; 97: 2222-9.

101 Vanhoutte PM. Endothelial dysfunction and atherosclerosis. Eur Heart J 1997; 18 Suppl E: E19-29.

102 Tesfamariam B, Jakubowski JA, Cohen RA. Contraction of diabetic rabbit aorta caused by endothelium-derived PGH2-TxA2. Am J Physiol 1989; 257: H1327-33.

103 Vita JA, Keaney JF Jr. Endothelial function: a barometer for cardiovascular risk? Circulation 2002; 106: 640-2.

104 Boulanger CM. Secondary endothelial dysfunction: hypertension and heart failure. J Mol Cell Cardiol 1999; 31: 39-49. 